\title{
PENGARUH SHELTER BERBEDATERHADAP PERTUMBUHAN DAN SINTASAN CRABLET KEPITING RAJUNGAN (Portunus pelagicus)
}

\author{
Effect of Different Shelters on Growth And Survival of Crabs Crablet Portunus pelagicus \\ Sri Wahyuni ${ }^{1}$, Sutia Budi ${ }^{2}$, Mardiana ${ }^{1}$ \\ ${ }^{1}$ Jurusan Budidaya Perairan Fakultas Pertanian Universitas Bosowa \\ ${ }^{2}$ Program Studi Budidaya Perairan Program Pascasarjana Universitas Bosowa \\ Email : sriw42138@gmail.com \\ Diterima: 03 Juli 2020 \\ Dipublikasikan: 05 Desember 2020
}

\begin{abstract}
ABSTRAK
Tujuan penelitian ini untuk mengetahui penggunaan shelter dalam meningkatkan kelulusan hidup dan menurunkan kanibalisme crablet rajungan (Portunus pelagicus). Penelitian ini di laksanakan selama 2 bulan di Balai Perikanan Budidaya Air Payau (BPBAP) Takalar. Salah satu upaya untuk mengurangi tingkat kanibalisme pada budidaya rajungan (Portunus pelagicus) adalah dengan pemberian shelter berupa Rumput laut Glacillaria, rumput sintetis, waring hitam. Rajungan (Portunus pelagicus) stadia crablet diperoleh dari BPBAP Jepara dengan berat awal 0.03 gram sedangkan berat akhir 0.64 gram, metode yang digunakan adalah rancangan acak lengkap dengan 4 perlakuan dan 3 ulangan. Hasil penelitian pengunaaan jenis shelter yang berbeda terhadap pertumbuhan mutlak dan panjang karapas yang bertujuan untuk mengurangi tingkat kanibalisme kepiting tidak berpengaruh nyata. Sedangkan hasil perhitungan sintasan Rajungan (Portunus pelagicus) dapat disimpulkan bahwa hasil penggunaan jenis shelter yang berbeda dapat berpengaruh nyata $(\mathrm{P}<0,01)$
\end{abstract}

Kata Kunci: Rajungan, Crablet, Shelter, Pertumbuhan, Sintasan

\section{ABSTRACT}

The aim of this study was to determine the use of shelter in increasing survival and reducing cannibalism of small crab (Portunus pelagicus) crablets. 'This research was carried out for 2 months at the Center for Brackish Water Aquaculture (BPBAP) Takalar. One effort to reduce the level of cannibalism in crab cultivation (Portunus pelagicus) is to provide shelter in the form of Glacillaria seaweed, synthetic grass, black waring. Crayfish (Portunus pelagicus) crablet stage was obtained from BPBAP Jepara with an initial weight of 0.03 grams and a final weight of 0.64 grams. The method used was a completely randomized design with 4 treatments and 3 replications. The results of the study using different types of shelter on absolute growth and carapace length aimed at reducing the level of crab cannibalism did not have a significant effect. While the results of the calculation of the survival of the crab (Portunus pelagicus) can be concluded that the results of using different types of shelters can have a significant effect $(\mathrm{P}<0.01)$

Keywords: Crabs, Crablet, Shleter, Growth, Survival

\section{PENDAHULUAN}

Rajungan (Portunus pelagicus) merupakan salah satu komoditas yang bernilai ekonomis penting di bidang perikanan, karena Rajungan termasuk jenis crustase komersial yang mempunyai nilai gizi tinggi yaitu protein $65,72 \%$, mineral 7,5\% dan lemak 0,88\% (Mania, 2007; Faidar et al. 2020). Selain itu Rajungan mudah dibudidayakan karena mudah berkembang biak, responsife terhadap makanan, dan cepat tumbuh (susanto et al 2005). Untuk memenuhi kebutuhan budiaya diperlukan suplai benih. Oleh karena itu langkah awal untuk meningkatkan produksi rajungan dari sektor budidaya adalah penyediaan benih rajungan yang siap tebar dan perbaikan benih Rajungan untuk memperoleh perbaikan dalam peningkatan kelangsungan hidup larva (Prastyanti et al., 2018; Yusneri et al. 2020). Namun penyedian ,larva masih terkendala tingkat kanibalisme yang cukup tinggi.

Permasalahan yang terjadi pada pembenihan Kepiting Rajungan adalah kanibalisme yang tinggi terutama pada larva Rajungan pada saat mengalami proses moulting mengakibatkan rendahnya sintasan dan pertumbuhan Rajungan yang dapat berdampak pada penurunan produksi (Budi et al. 2011; Budi et al. 2018). Salah satu solusidalam menekan kanibalisme pada perbenihan rajungan melalui rekayasa media budidaya dengan pemberian shelter. Shelter adalah tempat berlindungnya sehingga dapat menurunkan tingkat mortalitasi. Menurut Zmora et al.,(2007), menyatakan bahwa kanibalisme dapat ditekan dengan menggunakan shelter dan maupun substrat dasar yang cocok pada proses perbenihan serta pengurangan kepadatan.

Salah satu cara untuk mengurangi kanibalisme adalah penggunaan shelter yang merupakan tempat berlindungnya sehingga shelter memiliki peranan penting dalam memperkecil kematian yang disebabkan kanibalisme oleh karena itu perlu penambahan shelter yang berbeda, sehingga data yang diperoleh nantinya dapat dijadikan referensi guna pengembang an perbenihanRajungan. Tempat persembunyian atau shelter merupakan perlengkapan yang penting dalam budidaya Rajungan. Hal itu disebabkan sifat predator. Umumnya Rajungan bersembunyi untuk menghindari dari pemangsaan 
kepiting lainya. Tempat persembunyian ini dapat menambah luas permukaan tempat pemeliharaan, sehingga Rajungan dapat luas bergerak dengan demikian semakin banyak tempat berlindung, tingkat kanibalisme dikurangi dan tingkat kelangsungan hidup Rajungan (survival rate) lebih tinggi (Griffiths et al., 2008) Tempat persembunyian kepiting harus tersusun dengan baik yang tersedia dan penggunaannya dapat dikombinasikan untuk mendapatkan hasil yang maksimal. Berikut jenis-jenis tempat persembunyian kepiting rajungan.

Tujuan penelitian ini untuk mengetahui penggunaan shelter dalam meningkatkan kelulusan hidup dan menurunkan kanibalisme crablet rajungan (Portunus pelagicus). '

\section{METODE PENELITIAN}

\section{Tempat dan Waktu}

Penelitian ini dilaksanakan pada Bulan November 2019 sampai dengan Desember 2019 bertempat di Balai Perikanan Budidaya Air Payau Kabupaten Takalar (BPBAP).

\section{Bahan dan Peralatan Penelitian}

Wadah penelitian menggunakan baskom plastik hitam bervolume $30 \mathrm{~L}$ sejumlah 12 buah yang telah diisi air laut bersalinitas 34 ppt- Wadah tersebut dilengkapi dengan peralatan aerasi sehingga dapat mempertahankan suhu media penelitian. Penempatan wadah tersebut dilakukan secara acak. Untuk mempertahankan kelarutan oksigen media, maka pada setiap wadah diberi aerasi lemah dengan menggunakan selang yang dihubungkan dengan pipet pasteur.

Hewan Uji yang digunakan dalam penelitian ini adalah ben ih Rajungan yang stadia crablet (5) dengan kepadatan sebanyak 5 ekor /liter Suryanto, S, et al (2006)

\section{Metode penelitian}

Penelitian ini dilakukan dengan metode eksperimental. Komoditas yang diujikan adalah benih Rajungan. Penelitian ini dengan metode RAL dengan 4 perlakuan dan 3 ulangan dengan jenis shelter yang berbeda, yaitu:

- Perlakuan A = Rumput Laut Gracillaria sp

- Perlakuan B = Rumput Laut Sintetis

- Perlakuan $\mathrm{C}=$ Paranet

- Perlakuan D = Tanpa Shelter

\section{Parameter Uji}

Pertumbuhan Mutlak Ikan (Effendie, 2002)

Keterangan :

$$
\Delta w=\mathrm{W}_{t}-W_{i}
$$

$\mathrm{Wt}=$ Bobot akhir (gram)

$\mathrm{Wi}=$ Bobot awal (gram)

\section{Pertumbuhan Panjang Karapaks Kepiting Rajungan} (Zonneveld et al. 1991)

$$
\text { Panjang Carapaks }=\frac{(P t-P 0}{P 0} \times 100
$$

Keterangan :

$$
\mathrm{Pt} \quad=\text { Panjang akhir }
$$$$
\text { Po = Panjang awal }
$$

Sintasan (Effendie, 2002)

$$
S R=\frac{N t}{N 0} \times 100
$$

Keterangan :

$\mathrm{SR}=$ Tingkat sintasan (\%).

$\mathrm{Nt}=$ Jumlahra jungan hidup pada Akhir pemeliharaan (ekor).

No = Jumlah jungan pada awal pemeliharaan (ekor)

\section{Analisa Data}

Analisa data menggunakan exel dan ditunjukkan dalam bentuk tabel dan grafik dan akan dilanjutkan Anova dan bila hasilnya menunjukkan beda nyata akan dilanjutkan dengan Uji W-Tukey.

\section{HASIL DAN PEMBAHASAN}

\section{Laju Pertumbuhan Mutlak}

Hasil penelitian tentang pengaruh shelter berbeda terhadap pertumbugan dan sintasan crablet rajungan menunjukkan peningkatan nilai pertumbuhan (bobot) setiap minggu pada semua perlakuan. Berdasarkan hasil pengukuran di peroleh data pertumbuhan mutlak dapat dilihat pada Gambar 1.

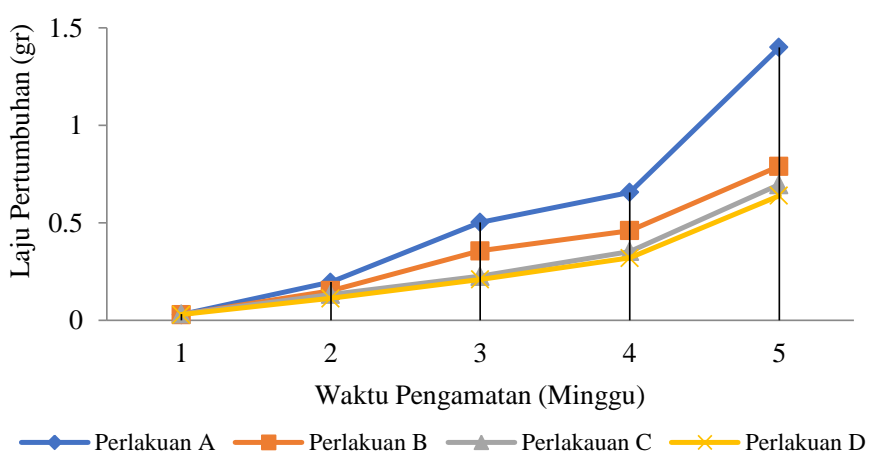

Gambar 1. Laju Pertumbuhan Mutlak Rajungan

Gambar 1., menunjukkan perlakuan A memiliki nilai pertumbuhan yang tinggi dibandingkan dengan perlakuan lainnya pada perlakuan A sebesar 140 gram pada hari ke 28, pada awal pengukuran nilai pertumbuhan perminggu pada setiap perlakuan memiliki nilai pertumbuhan yang sama yaitu sebesar 0.03 gram. Hasil analisis sidik ragam menunjukkan bahwa pengaruh perlakuan shelter yang berbeda tidak memberikan pengaruh terhadap pertumbuhan mutlak rajungan $(\mathrm{P}>0,05)$.

Hasil pengukuran pertumbuhan mutlak creblet Kepiting Rajungan (Portunus pelagius) pada perlakuan dengan menggunakan shelter memiliki nilai pertumbuhan mutlak lebih tinggi dibandingkan dengan perlakuan tanpa shelter. Tingkat pertumbuhan mutlak Kepiting Rajungan (Portunus pelagicus)

Nilai pertumbuhan mutlak rajungan terhadap shelter pada stadia crablet rata-rata selama penelitian yakni perlakuan A (rumput laut) sebesar 0,56 $\pm 0,53$ gram, perlakuan B (sintetis) sebesar 0,36 $\pm 0,29$ gram, perlakuan $\mathrm{C}$ (waring hitam) sebesar $0,29 \pm 0,26$ gram dan perlakuan $\mathrm{D}$ (kontrol) sebesar $0,26 \pm 0,24$ gram. pelindung rajungan yang dipelihara di dalam wadah jika dibandingkan dengan shelter sintetis, waring dan tanpa shelter. Hal ini menurut (Pirzat et al., 2007) disebabkan rumput laut 
tingkat kesuburannya lebih baik jika dibandingkan dengan shelter lainnya.. Suhayanto \& Tahe (2007) mendapatkan nilai pertumbuhan 8,3 $\pm 1,3$ gram. Sedangkan (Wenot et al.,2005), mendapatkan laju pertumbuhan kurang dari $50 \%$ dari bobot awal. Kedua penelitian tersebut menggunakan benih alam dan pakan berupa ikan rucah yang diberi secara rutin. Tingginya pertumbuhan mutlak pada minggu pertama sampai minggu ke-empat pada penelitian ini diduga karena kanibalisme yang tinggi. Hal ini sesuai pendapat dari Moller et al (2008) bahwa kanibalisme dapat secara langsung mempercepat pertumbuhan setiap perlakuan sehingga mengalami pertumbuhan yang berbeda anatar perlakauan lainnya

\section{Pertumbuhan Panjangn Karapaks Rajungan}

Hasil penelitan tentang pengaruh shelter berbeda terhadap pertumbuhan sintasan crable kepiting rajungan (Portunus pelagicus) menunjukkan peningkatan nilai pertumbuhan panjang karapas setiap minggu pada semua perlakuan. Berdasarkan hasil pengukuran di peroleh data pertumbuhan seperti yang tertera pada Gambar 2.

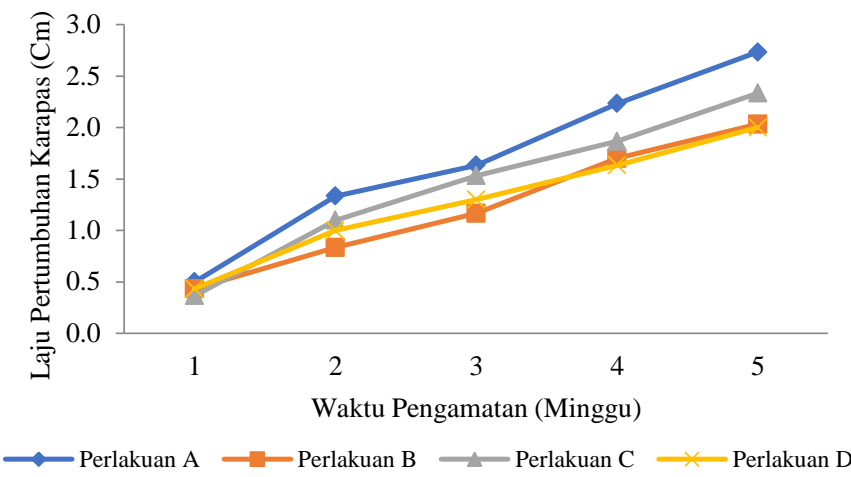

Gambar 2. Pertumbuhan Panjang Karapaks Rajungan

Gambar 2. diatas menunjukkan bahwa pertumbuhan panjang karapas tiap minggu memiliki nilai rata-rata tertinggi pada semua perlakuan, perlakuan A (Rumput Laut) sebesar 2,7 $\mathrm{cm}$, perlakuan B (Sintetis) sebesar $2.0 \mathrm{~cm}$, perlakuan C (Waring) sebesar $2.3 \mathrm{~cm}$, sedangkan perlakuan D (control) sebesar 2,0 cm. Hasil analisis sidik ragam menunjukkan bahwa pengaruh perlakuan shelter yang berbeda tidak memberikan pengaruh terhadap pertumbuhan panjang karapas $(\mathrm{P}>0,05)$. Berdasarkan gambar 2 ditas menunjukkan perlakuan A memiliki nilai pertumbuhan yang tinggi dibandingkan dengan perlakuan lainnya pada perlakuan A sebesar $2,7 \mathrm{~cm}$ pada hari ke 28, pada awal pengukuran nilai pertumbuhan panjang karapas pada setiap perlakuan memiliki nilai pertumbuhan yang sama yaitu sebesar $0.3-0,5 \mathrm{~cm}$.

Hasil pengukuran pertumbuhan panjang karapas pada crab Kepiting Rajungan (Portunus pelagicus) pada shelter rumput laut hal ini disebabkan kemarian rumput laut akibat fluktasi salinitas cukup tinggi akibat curah hujan yang sangat tinggi menyebabkan salinitas turun. Hal ini sangat mengganggu kehidupan rumput laut sebagai shelter, Menurut Lin (1974) rumput laut tumbuh paling cepata pada salinitas 25\% atau kisaran 18-30\% (Chen,1976). Salinitas optimum untuk rumput laut adalah $15-25 \%$. sebelum dan setelah molting menunjukkan bahwa peroses molting akan berakibat terhadap penambahan pertumbuhan panjang karapas. Hal ini diduga disebabkan pada proses molting terjadi penyerapan air dan perubahan volume karapas. Menurut Mykles (2001) kepiting saat molting meninggalkan karapas yang lama sambil menyerap air untuk memperbesar karapas yang baru. Fujaya (2008) menyatakan bahwa kepiting tidak dapat tumbuh secara linier, karena memiliki karapas yang keras.

\section{Sintasan (SR) Crablet Rajungan}

Sintasan atau kelangsungan hidup merupakan presentase kelangsunghidupan ikan selama masa pemeliharaan. Hasil penelitian tentang pengaruh shelter berbeda terhadap pertumbuha dan sintasn crablet kepiting rajungan menunjukkan nilai sintasan setiap minggu pada semua perlakuan. Berdasarkan hasil pengukuran diperoleh data seperti yang tertera pada Gambar 3 dibawah ini.

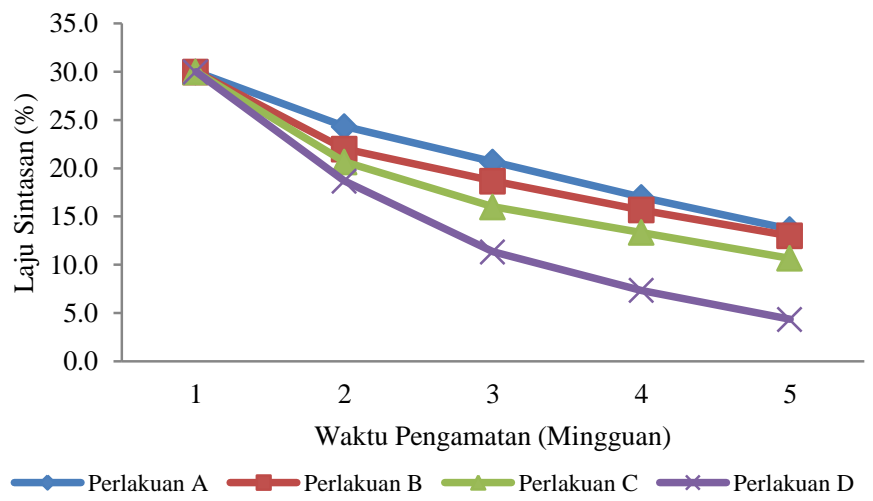

Gambar 3. Sintasan Crablet Rajungan

Gambar 3 diatas menunjukkan nilai kelangsungan hidup rajungan terhadap shelter pada stadia crablet rata-rata selama penelitian yakni perlakuan A (rumput laut) sebesar $21.1 \pm 6,4 \%$, perlakuan B (sintetis) sebesar 19,9 $\pm 6,6 \%$, perlakuan C (waring hitam) sebesar 18,1 $\pm 7,6 \%$ dan perlakuan D (kontrol) sebesar 4,3 $\pm 10,3 \%$. Hasil analisis sidik ragam menunjukkan bahwa pengaruh perlakuan shelter yang berbeda memberikan pengaruh nyata terhadap Sintasa rajungan $(\mathrm{P}>0,05)$. Hal ini menunjukan hasil yang baik, bila dibandingkan dengan penelitian sebelumnya, yaitu dengan laju sintasan tertinggi

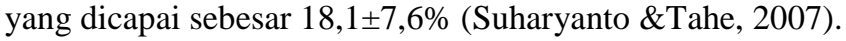

Hasil laju sintasan selama penelitian tersaji pada pada perlakuan A, laju sintasan yang tertinggi $(21.1 \pm 6,4 \%)$ diperoleh pasa shelter rumput laut dan diikuti shelter rumput sintetis, sherter waring hitam. Beberapa kemungkinan penyebab rajungan mati selain kanibalisme diantaranya adalah akibat stress nafsu makan rajungan dapat turun sehingga asupan gizi kurang dan kondisi tubuh melemah dan menyebabkan kematian. Kemudian pada saat proses ganti kulit (moulting). (Budi et al., 2018) rajungan memerlukan energi dan gerakan yang cukup kuat, maka bagi rajungan dewasa yang mengalami pergantian kulit membutuhkan energi dari pakan yang cukup besar. Jumlah kandungan nutrisi yang dihasilkan dari pakan yang diberikan mencukupi bagi rajungan untuk melakukan proses moulting, Borgstom (2002), mengemukakan bahwa sebagai organisme yang berhubungan dengan air, rajungan memperoleh energi dari makanan yang 
mereka dapatkan. Apabila kandungan energi berkurang makah protein dalam tubuh akan dipecah dan dipergunakan sebagai sumber energi. Energi yang diperlukan dalam proses moulting cukup besar, jika protein dipakai sebagai sumber energi tidak mencukupi maka hal tersebut juga dapat menyebabkan kematian rajungan pada saat moulting. Dari hasil yang diperoleh dapat dikatakan bahwa, shelter rumput laut masih lebih baik sebagai pelindung rajungan yang di pelihara dalam wadah jika dibandingkan dengan shelter lainnya.

Hal tersebut menunjukkan bahwa dapat berfungsinya substrat dasar sebagai shelter pada pemeliharaan creblet Kepiting Rajungan. Dikarenakan rajungan pada stadia crablet saat moulting dapat berlidung pada shelter. Sehingga tidak dapat dimangsa oleh rajungan lain yang tidak mengalami moulting. Marshall et al (2005) menyatakan bahwa rajungan pada stadia crablet kondisinya sangat rentang dibandingkan dengan yang berukuran lebih besar, Rajungan pada ukuran tersebut menunjukkan sifat agitasi yang sangat tinggi sehingga berakibat mortalitasnya juga tinggi. Semakin besar kesempatan untuk berlindung secara propesional memperbesar tingkat kelangsungan hidup dan menunjukkan bahwa kuantitas shelter lebih besar pengaruhnya untuk menurunkan tingkat kanibalisme pada Rajungan (Portunus pelagicus), sedangkan menurut Stevens dan Swiney (2005) habitat tertentu sebagai shelter dapat melindungi rajungan dari predator terutama terutama pada awal stadia crablet, tetapi hasil penelitian menunjukkan bahwa shelter dapat berpengaruh nyata terhadap sintasan Rajungan . Hal ini terdapat kecenderungan semakin tinggi pada penebaran semakin rendah laju sintasan crablet Rajungan yang dipelihara (Prastyanti et al., 2018) bila dibandingkan dengan penelitian sebelumnya .

\section{KESIMPULAN}

Hasil penelitian menunjukkan bahwa pengunaaan jenis shelter yang berbeda terhadap pertumbuhan mutlak dan panjang karapas yang bertujuan untuk mengurangi tingkat kanibalisme kepiting tidak berpengaruh nyata. Sedangkan hasil perhitungan sintasan Rajungan (Portunus pelagicus) dapat disimpulkan bahwa hasil penggunaan jenis shelter yang berbeda dapat berpengaruh nyata. Berdasarkan hasil penelitian disarankan bahwa perlu dilakukan penelitian lanjutan penggunaan shelter yang ideal guna untuk meningkatkan pertumbuhan dan sintasan rajungan.

\section{DAFTAR PUSTAKA}

Adi, Y. S. 2011. Sintasan Larva Rajungan (Portunus pelagicus) Stadia Zoea sampai crablet Pada Berbagai Frekuensi pemberian pakan. Fakultas Pertanian Universitas Muhammadia Makassar.

Ario, R., Djunaedi, A., Pratikto, I., Subardjo, P., \& Farida, F. (2019). Perbedaan Metode Mutilasi Terhadap Lama Waktu Molting Scylla serrata. Buletin Oseanografi Marina.

Basmal, J., Prasetyo, A., \& Farida, Y. (2007). Pengaruh Suhu Eterifikasi Terhadap Kualitas Dan Kuantitas Kitosan Larut Air Yang Dibuat Dari Cangkang Rajungan. Jurnal Pascapanen Dan Bioteknologi Kelautan Dan Perikanan
Budi, S., \& Aslamsyah, S. (2011). Improvement of the Nutritional Value and Growth of Rotifer (Brachionus plicatilis) by Different Enrichment Period with Bacillus sp. Jurnal Akuakultur Indonesia, 10(1), 67-73.

Budi, S., \& Zainuddin, Z. (2012). Peningkatan Asam Lemakrotifer Brachionus Plicatilis Dengan Periode Pengkayaan Bakteri Bacillus Sp. Berbeda. Octopus: Jurnal Ilmu Perikanan, 1(1), 1-5.

Budi, S., Karim, M. Y., Trijuno, D. D., Nessa, M. N., Gunarto, G., \& Herlinah, H. (2016). The use of fatty acid omega-3 HUFA and Ecdyson Hormone To Improve Of Larval Stage Indeks and Survival Rate Of Mud Crab Scylla olivacea. Simposium Nasional Kelautan dan Perikanan, 3 , 487-498.

Budi, S., Karim, M. Y., Trijuno, D. D., Nessa, M. N., \& Herlinah, H. (2018). Pengaruh Hormon Ecdyson Terhadap Sintasan Dan Periode Moulting Pada Larva Kepiting Bakau Scylla olivacea. Jurnal Riset Akuakultur, 12(4), 335-339.

Djunaedi, A. (2016). Pertumbuhan dan Prosentase Molting pada Kepiting Bakau (Scylla serrata Forsskäl,1775) dengan Pemberian Stimulasi Molting Berbeda. Jurnal Kelautan Tropis. https://doi.o rg/10.14710/jkt.v19i1.597

Effendi, 2002. Biologi Perikanan. Cetakan Kedua. Yayasan Pustaka Nusantara, Yogyakarta. $163 \mathrm{hlm}$.

Faidar, F., Budi, S., \& Indrawati, E. (2020). Analisis Pemberian Vitamin C Pada Rotifer dan Artemia Terhadap Sintasan, Rasio Rna/Dna, Kecepatan Metamorfosis Dan Ketahanan Stres Larva Rajungan (Portunus Pelagicus) Stadia Zoea. Journal of Aquaculture and Environment, 2(2), 30-34.

Fujaya, Y., \& Alam, N. (2012). Pengaruh kualitas air, sirkulasi bulan, dan pasang surut terhadap molting dan produksi kepiting cangkang lunak (soft shell crab) di tambak komersil. Pertemuan Ilmiah Tahunan ISOI.

Griffiths, G. J. K., Holland, J. M., Bailey, A., \& Thomas, M. B. (2008). Efficacy and economics of shelter habitats for conservation biological control. Biological Control. https://doi.org/10.1016/j.biocontrol.2007.09.002

Kordi, M. Ghufrandaan AB. Tancung.2007. Pengelolaan Kualitas Air dalam Budidaya Perairan. Rineka Cipta. Jakarta.

Marshall, S.,(2005) Canibalisme in juvenile blue-swimmer crabs Portunus pelagicus

Moller and D.Man.2008. Cnibalism Contributes Signifikantly to the Diet of Cultured Sand Crabs (Portunuspelagicus Linn).: A Anal Stable Isotope Study. Yogyakarta.

Mykles, D.L. 2001. Interactions Betwan Limb Regeneration and Moulting in Decapod Crustacean. Amerika Zoology

Nawaly, H., Susanto, A. ., \& Uktolseja, J. L. . (2011). Senyawa Bioaktif dari Rumput Laut sebagai Antioksidan. Jurnal Seminar Nasional x Pendidikan Biologi FKIP UNS. https://doi.org/10.1111/ele.12469

Prabowo rahardjo, S. S. (2019). Pengaruh Pemberian Pakan Mikro terhadap Pertumbuhan Larva Rajungan (Portunus pelagicus). Journal of Aquaculture and Fish Health. 
https://doi.org/10.20473/jafh.v8i1.11819

Prastyanti, K. A., Andriani, Y.-, Yustiati, A., \& Sunarto, S. (2018). Kelangsungan Hidup Dan Pertumbuhan Larva Rajungan (Portunus Pelagicus) Melalui Pemberian NauPLIUS Artemia

Rianta Pratiwi. (2014). Karakteristik morfologi kepiting mangrove Uca spp. (Crustacea:Decapoda:Ocypodidae) | Lembaga Ilmu Pengetahuan Indonesia. Oseana.

Sahat, H. J. (2013). Rumput Laut Indonesia. Warta Ekspor Kementerian Perdagangan RI.

Serosero, R. (2011). Karakteristik habitat kepiting bakau (Scylla spp) di perairan pantai Desa Todowongi Kecamatan Jailolo Selatan Kabupaten Halmahera Barat. Agrikan: Jurnal Ilmiah Agribisnis Dan Perikanan. https://doi.org/10.29239/j.agrikan.4.1.69-73

Shantika, Z. R., Srikandi, S., \& Sutamihardja, R. (2019). Ekstraksi Rumput Laut Gelidium Sp. Menjadi Bakto Agar Sebagai Pemadat Media Pertumbuhan Mikroba. Jurnal Sains Natural. https://doi.org/10.31938/jsn.v9i2.234

Wedemeyer GA. 2001. Fish Hatchery Management.2nd Edition. Bethesda. American Fisheries Society. Maryland.

Waring, R., \& Knight, R. (2013). How should children with speech sound disorders be classified? A review and critical evaluation of current classification systems.. https://doi.org/10.1111/j.1460-6984.2012.00195.x

Yulistiani R, S. dan A. T. (2013). Sistem Emulsi Sosis Sintetis Dari Gluten Dan Rumput Laut (Euchema cottoni) (Synthetic Sausage Emulsion System of Gluten and Seaweed). REKAPANGAN.

Yusneri, A., Budi, S., \& Hadijah, H. (2020). Pengayaan Pakan Benih Rajungan (Portunus Pelagicus) Stadia Megalopa Melalui Pemberian Beta Karoten. Journal of Aquaculture and Environment, 2(2), 39-42.

Zaidin, M. Z., Effendy, I. J., \& Sabilu, D. K. (2013). Sintasan Larva Rajungan (Portunus pelagicus) Stadia Megalopa Melalui Kombinasi Pakan Alami Artemia salina dan Brachionus plicatilis. Jurnal Mina Laut Indonesia.

Zonneveld, C. 1991. Estimating death rates from transect counts. Ecological Entomologi. 16. Gramedia, Jakarta. 